\title{
Yellow gentian root extract provokes concentration- and time-dependent response in peripheral blood mononuclear cells
}

\author{
Ana Valenta Šobot, Dunja Drakulić, Gordana Joksić, Jadranka Miletić Vukajlović, Jasmina Savić, \\ Jelena Potočnik, and Jelena Filipović Tričković
}

Vinča Institute of Nuclear Sciences - National Institute of the Republic of Serbia, University of Belgrade, Belgrade, Serbia

[Received in August 2020; Similarity Check in August 2020; Accepted in October 2020]

Yellow gentian (Gentiana lutea L.), a medicinal plant widely used in traditional medicine, displays multiple biological effects, ranging from beneficial to toxic. Since many promising applications have been reported so far, our aim was to evaluate its potential concentration- and time- dependent cytotoxic and genotoxic effects in vitro. To that end we exposed human peripheral blood mononuclear cells to $0.5,1$, and $2 \mathrm{mg} / \mathrm{mL}$ of yellow gentian root extract (YGRE) to determine its effects on oxidative stress parameters [pro/antioxidant balance (PAB) and lipid peroxidation], DNA damage (alkaline comet assay and chromosome aberrations), and cell viability (trypan blue exclusion test). Cell viability decreased with increasing concentrations and treatment duration. Only the lowest YGRE concentration $(0.5 \mathrm{mg} / \mathrm{mL})$ increased oxidative stress but produced minor DNA damage and cytotoxicity. At higher concentrations, redox parameters returned to near control values. The percentage of chromosome aberrations and percentage of DNA in the comet tail increased with increased YGRE concentration after $48 \mathrm{~h}$ and declined after $72 \mathrm{~h}$ of treatment. This points to the activation of DNA repair mechanism (homologous recombination), evidenced by the formation of chromosomal radial figures after $72 \mathrm{~h}$ of treatment with the highest YGRE concentration of $2 \mathrm{mg} / \mathrm{mL}$. Our results suggest that YGRE, despite induction of cytotoxic and genotoxic effects, activates cell repair mechanisms that counter oxidative and DNA lesions and induce cell death in highly damaged cells. Therefore, observed protective effects of yellow gentian after longer exposure could be a result of activated repair and removal of cells with irreparable damage.

KEY WORDS: cytotoxicity; genotoxicity; Gentiana lutea L.; homologous recombination; redox parameters

\section{List of abbreviations}

CA- chromosome aberrations; DAPI - 4', 6'- diamidino2-phenylindole; DMSO - dimethyl sulphoxide; DSBs double-strand breaks; DPPH - 2,2-diphenyl-1picrylhydrazyl; EDS - energy dispersive spectroscopy; FESEM - field emission scanning electron microscopy; GSH - glutathione; HNE - 4-hydroxyalkenals; HR homologous recombination; HRP - horse radish peroxidase; LMPA - low melting point agarose; LPP - lipid peroxidation products; MDA - malondialdehyde; NMPA - normal melting point agarose; $\mathrm{PAB}$ - pro/antioxidant balance; PBMC - peripheral blood mononuclear cells; PBS phosphate buffer saline; ROS - reactive oxygen species; SOD - superoxide dismutase; TB - trypan blue; TMB 3,3',5,5'-tetramethylbenzidine; UPLC - ultra performance liquid chromatography; YGRE - yellow gentian (Gentiana lutea L.) root extract;

Corresponding author: Jelena Filipović Tričković, Vinča Institute of Nuclear Sciences - National Institute of the Republic of Serbia, University of Belgrade, Mike Petrovića Alasa 12-14, 11001 Belgrade, Serbia

E-mail:filipovicj@vin.bg.ac.rs,jelena.fil@hotmail.com
Yellow gentian (Gentiana lutea L.) belongs to the Gentianaceae family, which is common in the mountainous regions of Europe, Southeast Asia, and North America (1). Virtually all plant parts (leaves, flowers, rhizomes, roots) or whole plants are used in traditional medicine. The root has been used to mitigate gastrointestinal disorders for thousands of years. It is also used to support gallbladder and liver functions and treat dyspepsia, anorexia, fever, sore throat, and rheumatic pain (2). It has a bitter taste due to the presence of triterpenoids, amarogentin and gentiopicroside in particular. Its extract contains many other bioactive compounds, such as xantones, flavonoids, and iridoids $(1,3)$, some of which exhibit beneficial antiinflammatory, antioxidative, radioprotective, immunomodulatory, and antimicrobial effects $(2,4-7)$. Some reports suggest that the root extract has a potential to prevent and treat obesity, prevent insulin resistance and type 2 diabetes mellitus, and to mitigate cardiovascular complications, including atherosclerosis $(8-10)$.

Therefore, it is hardly surprising that yellow gentian extract has been the subject of numerous pharmacological studies in recent years. However, several have reported that crude extract can cause oxidative and genotoxic damage, disturb cell proliferation, and trigger cell death (11-13). Its 
cytotoxic effects have also been demonstrated against malignant cell lines, suggesting that yellow gentian extract has a potential for anticancer treatment $(14,15)$.

Taking into account multiple biological effects of yellow gentian, widespread traditional use and high potential for applications, evaluation of its cytotoxicity and genotoxicity are essential.

The aim of this study was to evaluate in vitro effects of yellow gentian root extract (YGRE) applied at different concentrations on redox parameters (pro/antioxidant balance and lipid peroxidation), DNA damage, and survival of human peripheral blood mononuclear cells after 48 and $72 \mathrm{~h}$ of treatment.

\section{MATERIALS AND METHODS}

\section{Yellow gentian root extract (YGRE) preparation}

Yellow gentian root (serial number 03970219) was purchased from the Institute of Medicinal Plant Research "Dr Josif Pančić", Belgrade, Serbia (CAC/RCP 1-1969, rev.4-2003). Before extraction, the root was ground with a hand grinder. In order to optimise and standardise the extraction technique, ground particles were imaged after each stage of extract preparation, namely powder, lyophilisate, and dissolved lyophilisate (Figure 1), with a field emission scanning electron microscope (FESEM) with energy dispersive spectroscope (EDS) (FEI SCIOS 2, Thermo Fisher Scientific FEI Company, Tokyo, Japan) at 350x magnification and their size determined with SemAfore 5.2 software (Insinööritoimisto J. Rimppi Oy, Ojakkala, Finland)

The obtained aqueous extract was placed in $25 \mathrm{~mL}$ acrylic chambers, transferred in the freezer at $-18{ }^{\circ} \mathrm{C}$ and allowed to freeze for $24 \mathrm{~h}$. Pre-frozen supernatant was then vacuum freeze-dried under vacuum pressure of $400 \mathrm{~Pa}$ for $48 \mathrm{~h}$.

Before dissolving, lyophilised powder was kept in a desiccator at $4{ }^{\circ} \mathrm{C}$ and then dissolved in $50 \%$ ethanol to obtain the concentration of $50 \mathrm{mg} / \mathrm{mL}$. Particle size measurements showed that lyophilised particle aggregates consisted of soluble compounds. Dissolved lyophilisate was filtered through a $0.2 \mu \mathrm{m}$ pore diameter Minisart ${ }^{\circledR}$ filter (Sartorius, Göttingen, Germany) in order to eliminate the remaining non-soluble particles and sterilise the extract solution. The filtrate was to determine the concentration of secoiridoids in the extract. The final extract concentrations in cell cultures were $0.5,1$, and $2 \mathrm{mg} / \mathrm{mL}$.

\section{Ultra performance liquid chromatography (UPLC)}

Chromatographic separations of YGRE constituents were done by ACQUITY UPLC system (Malvern Panalytical Ltd, Malvern, UK) with a photodiode array (PDA) detector and a LUNA $3 \mathrm{u}, \mathrm{C} 18(2), 3 \mu \mathrm{m}$, $100 \mathrm{~mm} \times 2 \mathrm{~mm}$ Phenomenex column as a stationary phase
(Phenomenex, Torrance, CA, USA). All analyses were done under the gradient condition (Table 1), with a mobile phase consisting of solvent $\mathrm{A}(0.1 \mathrm{wt} \% \mathrm{HCOOH}$ in water $)$ and solvent $\mathrm{B}(0.1 \mathrm{wt} \% \mathrm{HCOOH}$ in methanol) at a constant flow rate of $0.3 \mathrm{~mL} / \mathrm{min}$. Autosampler was maintained at $4{ }^{\circ} \mathrm{C}$. 3D chromatograms were recorded in the wavelength range of 210-450 $\mathrm{nm}$. The run time was $6 \mathrm{~min}$, and the injection volume $3.5 \mu \mathrm{L}$.

\section{Isolation and cultivation of human peripheral blood mononuclear cells}

Peripheral blood samples were collected in Li-heparin vacutainers $(2 \times 10 \mathrm{~mL})$ from three healthy donors aged 20 to 40 years. All subjects signed informed consent, and the study was approved by the Ethics Committee of the Vinča Institute of Nuclear Sciences - National Institute of the Republic of Serbia.

Peripheral blood mononuclear cells (PBMC) were isolated in Ficoll ${ }^{\mathrm{TM}}$ medium (Thermo Fisher Scientific, Waltham, MA, USA) and resuspended in RPMI 1640 medium supplemented with $1 \%$ penicillin-streptomycin and $10 \%$ foetal bovine serum (FBS) at a concentration of $1 \times 10^{6}$ viable cells $/ \mathrm{mL}$. The obtained cell cultures were then incubated with root extract at $37^{\circ} \mathrm{C}$ for 48 and $72 \mathrm{~h}$.

\section{Trypan blue exclusion test}

Trypan blue was used to evaluate cell viability as described elsewhere (17). Briefly, equal volumes of PBMC suspension and $0.4 \%$ Trypan blue dye were mixed and applied to a haemocytometer (Cambridge Instruments Inc., Buffalo, NY, USA). Live, unstained cells were counted in four sets of 16 squares. Viable cell counts per $\mathrm{mL}$ represent the mean of each set, multiplied by $10^{4}$ and by 2 as dye dilution correction factor.

\section{Chromosome aberrations assay}

To establish cell cultures, $0.5 \mathrm{~mL}$ of heparinised whole blood was added in RPMI 1640 medium supplemented with $1 \%$ penicillin-streptomycin, $10 \%$ FBS, and phytohaemagglutinin and treated with YGRE to obtain final concentrations of $0.5,1$, and $2 \mathrm{mg} / \mathrm{mL}$. All chemicals used for cell culture were purchased from Capricorn Scientific GmbH (Ebsdorfergrund, Germany). Harvesting was performed 48 and $72 \mathrm{~h}$ after culture initiation. Three hours before harvesting, colchicine (Sigma-Aldrich Co., St. Louis, MO, USA) was added (in the final concentration of $2.5 \mu \mathrm{g} /$

Table 1 Gradient condition details used for UPLC separation.

\begin{tabular}{cc}
\hline time $(\mathrm{min})$ & $\% \mathrm{~B}$ \\
\hline $0 \rightarrow 2$ & $10 \rightarrow 28$ \\
\hline $2 \rightarrow 3.5$ & $28 \rightarrow 30$ \\
\hline $3.5 \rightarrow 5$ & $30 \rightarrow 55$ \\
\hline $5 \rightarrow 5.1$ & $55 \rightarrow 10$ \\
\hline $5.1 \rightarrow 6$ & $10 \rightarrow$ \\
\hline
\end{tabular}


$\mathrm{mL})$ to collect metaphase cells. Cell cultures were then centrifuged and treated with hypotonic solution $(0.56 \%$ $\mathrm{KCl})$ at $37^{\circ} \mathrm{C}$ for $20 \mathrm{~min}$. The supernatant was removed and cells fixed in Carnoy's fixative solution (3:1 methanolto-glacial acetic acid ratio), washed three times in fixative, and pipetted on clean microscopic slides. Slides were dehydrated with increasing concentrations of ethanol (70, 95, and $100 \%$ ), stained with 4',6'- diamidino-2-phenylindole (DAPI)-containing Vectashield solution (Vector Laboratories Ltd, Peterborough, UK), and analysed under a ZeissAxioimager A1 microscope (Carl Zeiss, Jena, Germany), with the ISIS imaging software package (MetaSystems Hard \& Software GmbH, Altlussheim, Germany). At least 200 complete metaphase spreads per sample were analysed, whereas the scoring criteria included determination of karyotype and indicators of chromosome damage (chromosome breaks, dicentric and ring chromosomes, acentric fragments, and radial figures) $(18,19)$.

\section{Alkaline comet assay}

The alkaline comet assay was an adaptation of the method described by Singh et al. (20). Briefly, PBMC treated for $48 \mathrm{~h}$ were washed in phosphate buffer saline (PBS), resuspended in $1 \%$ low melting point agarose (LMPA) in PBS at $37^{\circ} \mathrm{C}$, and placed on microscopic slides precoated with a thin layer of $1 \%$ normal melting point agarose (NMPA). Slides were allowed to settle at $4{ }^{\circ} \mathrm{C}$ for $10 \mathrm{~min}$ and then immersed in a lysis solution at $4{ }^{\circ} \mathrm{C}$ for $1 \mathrm{~h}$. Electrophoresis was performed at the same temperature and voltage of $25 \mathrm{~V}(1 \mathrm{~V} / \mathrm{cm}, 300 \mathrm{~mA})$ for $20 \mathrm{~min}$. Slides were then washed three times in $0.4 \mathrm{~mol} / \mathrm{L}$ Tris- $\mathrm{HCl}, \mathrm{pH}$ 7.5 , at $4{ }^{\circ} \mathrm{C}$, air dried, and counterstained with a DAPIcontaining Vectashield solution. At least 300 cells were evaluated for each slide under a Zeiss-Axioimager A2 microscope with automated Metafer CometScan software (MetaSystems). The results are presented as the percentage of DNA in the comet tail (\% DNA).

\section{Prooxidant-antioxidant balance (PAB) assay}

The assay was done as described by Alamdari et al. (21), with minor modifications. This method is based on two concomitant oxidation-reduction reactions in the same sample. In the first reaction, catalysed by horse radish p e r oxidase ( H R P), chromoge $n$ $3,3^{\prime}, 5,5^{\prime}$-tetramethylbenzidine (TMB) is oxidised to a coloured cation. In the second reaction, this coloured cation is reduced by antioxidants to a colourless compound.

Standard solution was prepared by mixing different proportions (0-100\%) of $1 \mathrm{mmol} / \mathrm{L} \mathrm{H}_{2} \mathrm{O}_{2}$ with $6 \mathrm{mmol} / \mathrm{L}$ uric acid in $10 \mathrm{mmol} / \mathrm{L} \mathrm{NaOH}$. To prepare solution of TMB cation, a mixture of $0.1 \mathrm{~mL} \mathrm{TMB} / \mathrm{DMSO}(6 \mathrm{mg} / \mathrm{mL}), 5 \mathrm{~mL}$ acetate buffer $(0.05 \mathrm{mmol} / \mathrm{L}, \mathrm{pH} 4.5)$ and $17.5 \mu \mathrm{L}$ freshly made chloramine $\mathrm{T}(100 \mathrm{mmol} / \mathrm{L})$, was mixed, shacked for $1 \mathrm{~h}$ at $37^{\circ} \mathrm{C}$, and incubated in a dark place. Then $2.5 \mathrm{U}$ of enzyme solution HRP was added to this mixture. TMB solution II was made of $0.1 \mathrm{~mL}$ TMB/DMSO $(6 \mathrm{mg} / \mathrm{mL})$ and $5 \mathrm{~mL}$ acetate buffer $(0.05 \mathrm{~mol} / \mathrm{L}, \mathrm{pH} 5.6)$.

In each well of reaction plate, $10 \mu \mathrm{L}$ of sample/standard/ blank was mixed with $180 \mu \mathrm{L}$ of working solution, freshly made from $0.5 \mathrm{~mL}$ of TMB cation and $5 \mathrm{~mL}$ TMB solution II that were mixed for $6 \mathrm{~min}$ at room temperature in the dark. Then, the plate was incubated for $12 \mathrm{~min}$ at $37^{\circ} \mathrm{C}$, in a dark place. The reaction was stopped by adding $40 \mu \mathrm{L}$ of $2 \mathrm{~mol} / \mathrm{L} \mathrm{HCl}$ to each well.

The difference between these parallel reactions was measured as optical density (OD) at $450 \mathrm{~nm}$ wavelength, with a reference wavelength of $570 \mathrm{~nm}$ on absorbance microplate reader Sunrise (Tecan Group Ltd, Männedorf, Switzerland). The PAB values were calculated from the standard curve that represents the percentage of hydrogen peroxide in the standard solution and were expressed in arbitrary Hamidi-Koliakos (HK) units.

\section{Lipid peroxidation product (LPP) assay}

Lipid peroxidation product (LPP) assay used in this study is based on the reaction of chromogen $N$-methyl-2phenylindole with products of lipid peroxidation, namely malondialdehyde (MDA) and 4-hydroxyalkenals (HNE) $(22,23)$.

After treatment, cells were washed and lysed in $0.9 \%$ $\mathrm{NaCl}$ in freeze-thaw cycles. An aliquot of the samples was used for protein determination. The reaction mixture contained $140 \mu \mathrm{L}$ of sample/standard/blank, $455 \mu \mathrm{L}$ of reagent diluted in acetonitrile/methanol (3:1) to a final concentration of $10 \mathrm{mmol} / \mathrm{L}$, and $105 \mu \mathrm{L}$ of methanesulphonic acid containing $34 \mu \mathrm{mol} / \mathrm{L} \mathrm{Fe}(\mathrm{III})$. It was added to microcentrifuge tubes, vortexed, and incubated at $45^{\circ} \mathrm{C}$ for $60 \mathrm{~min}$. Samples were centrifuged at $15000 \mathrm{xg}$ for $10 \mathrm{~min}$ to obtain a clear supernatant.

The product of this reaction is a stabile chromophore, whose OD value was measured at $586 \mathrm{~nm}$ on the Sunrise absorbance microplate reader (Tecan). The values are presented as nmol of LPP per mg of protein using a standard curve of 1,1,3,3-tetramethoxypropane.

\section{Statistical analysis}

All experiments were done in duplicate and repeated three times. The results are presented as means \pm standard error (SE). ANOVA test and Pearson correlation coefficient were used for statistical analysis. The level of significance was set at $\mathrm{p}<0.05$. All statistical analyses were run on the SPSS 10 for Windows (IBM, Armonk, NY, USA). 


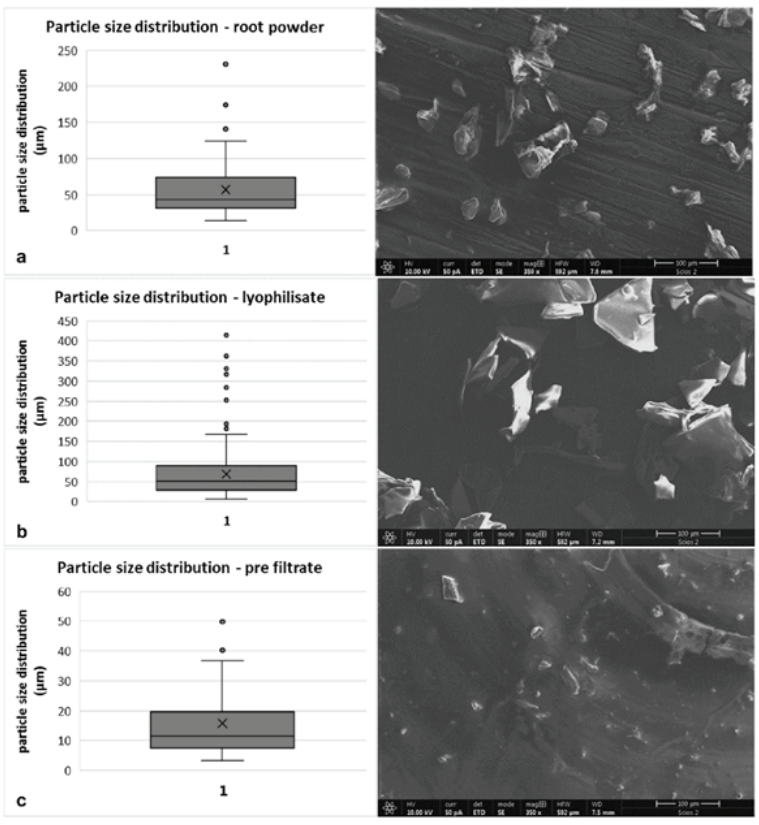

Figure 1 Particle size distribution of dispersed particles in (a) yellow gentian root powder; (b) lyophilisate; and (c) dissolved lyophilisate (pre-filtrate). Scale bar $-100 \mu \mathrm{m}$

\section{RESULTS}

Characterisation of yellow gentian root extract (YGRE) particle sizes by Field Emission Scanning Electron Microscopy (FESEM) with energy dispersive spectroscopy $(E D S)$

Analysis of FESEM photomicrograph showed that the particle size in dispersed root powder was $53.9 \pm 2.95 \mu \mathrm{m}$ (Figure $1 \mathrm{a}$ ). After filtration and lyophilisation, the particles displayed laminar or plate-like structure: smaller particles formed aggregates, whose average dimension was $68.4 \pm 3.6 \mu \mathrm{m}$ (Figure $1 \mathrm{~b}$ ). The aggregates were mostly composed of soluble compounds, since particles observed in the lyophilisate dissolved in $50 \%$ ethanol (concentration of $50 \mathrm{mg} / \mathrm{mL}$ ) were of a much smaller dimension $15.8 \pm 1.3 \mu \mathrm{m}$ (Figure $1 \mathrm{c}$ ).

Ultra performance liquid chromatography (UPLC) with PDA detector

Analytical standards of selected compounds were used to identify some of the most intensive peaks in chromatogram. Detailed data are presented in the report by Valenta Šobot et al. (24). Figure 2 shows UPLC chromatograms of YGRE ethanolic solution exported from 3D chromatograms at three wavelengths, revealing a high content of gentiopicroside and high stability of other compounds during treatment.

\section{Cell viability}

Figure 3a shows results of cell viability assay. All treatments reduced cell viability to a certain extent ranging from mild ( $91.84 \%$ for $0.5 \mathrm{mg} / \mathrm{mL}, 48 \mathrm{~h}$ treatment) to more noticeable $(59.54 \%$ for $2 \mathrm{mg} / \mathrm{mL}, 72 \mathrm{~h}$ treatment, $\mathrm{p}<0.001)$. Cell viability decreases with increasing YGRE concentration, at both exposure times. Statistically significant reduction was observed for concentrations of 1 and $2 \mathrm{mg} / \mathrm{mL}$ for both $48(\mathrm{p}<0.05$ and $\mathrm{p}<0.01$, respectively) and $72 \mathrm{~h}$ treatment $(p<0.01$ and $p<0.001$, respectively, Figure $3 a)$.

\section{Incidence of chromosome aberrations}

The results of chromosome aberrations assay showed that incidence of chromosomal breaks increased with the increase of YGRE concentration after $48 \mathrm{~h}$ of treatment, from $0.8 \%(0.5 \mathrm{mg} / \mathrm{mL})$ to $8.11 \%(2 \mathrm{mg} / \mathrm{mL})$ (Figure 3 b). Chromosome aberrations were also analysed after $72 \mathrm{~h}$ to evaluate the impact of prolonged incubation on DNA damage repair. The trend of increasing frequency of breaks was noticed after $72 \mathrm{~h}$ treatment for concentrations of 1 and $2 \mathrm{mg} / \mathrm{mL}$ (0.93 and $5.1 \%$, respectively), however the percentage of breaks was reduced comparing to $48 \mathrm{~h}$ treatment (Figure 3). The concentration of $0.5 \mathrm{mg} / \mathrm{mL}$ did not induce chromosomal breaks after $72 \mathrm{~h}$. Figure 4 shows the appearance radial figures between homologous chromosomes at $2 \mathrm{mg} / \mathrm{mL}$ of YGRE, which are indicators of double-strand break (DSB) repair.

As expected, the percentage of chromosome breaks inversely correlated with viability assay for both treatment times $(\mathrm{p}<0.01, \mathrm{r}=-0.67$ for $48 \mathrm{~h}$ treatment and $\mathrm{p}<0.01$, $\mathrm{r}=-0.89$ for $72 \mathrm{~h}$ treatment).

\section{Comet assay}

All tested YGRE concentrations increased the percentage of DNA in the comet tail compared to control after $48 \mathrm{~h}$ of treatment and the difference was significant for the two higher concentrations $(p<0.001)$ (Figure 5). Again, as expected, the parameter percentage of DNA in the comet tail inversely correlated with cell viability $(\mathrm{p}<0.01, \mathrm{r}=-0.797)$.

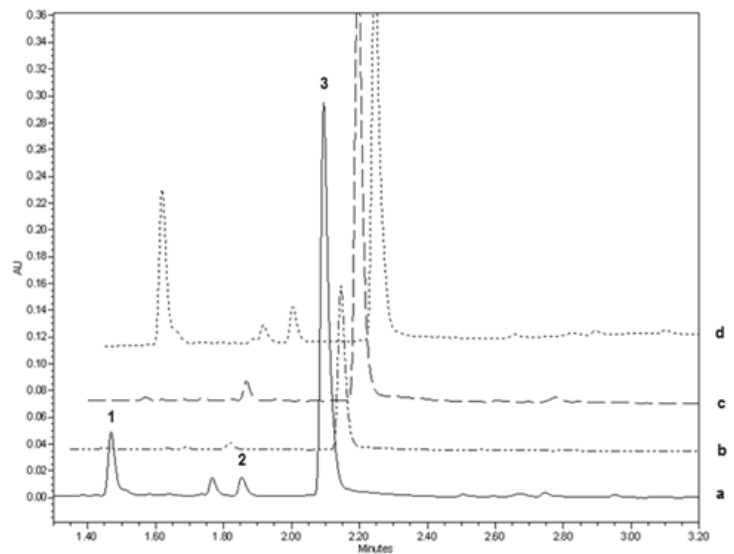

Figure 2 UPLC chromatograms of yellow gentian root extract in ethanol solution exported at $254 \mathrm{~nm}$ (a); $300 \mathrm{~nm}$ (b); $270 \mathrm{~nm}$ (c); and $240 \mathrm{~nm}$ (d). 1 - loganic acid; 2 - swertiamarin; 3 - overlapping gentiopicroside and sweroside peaks 

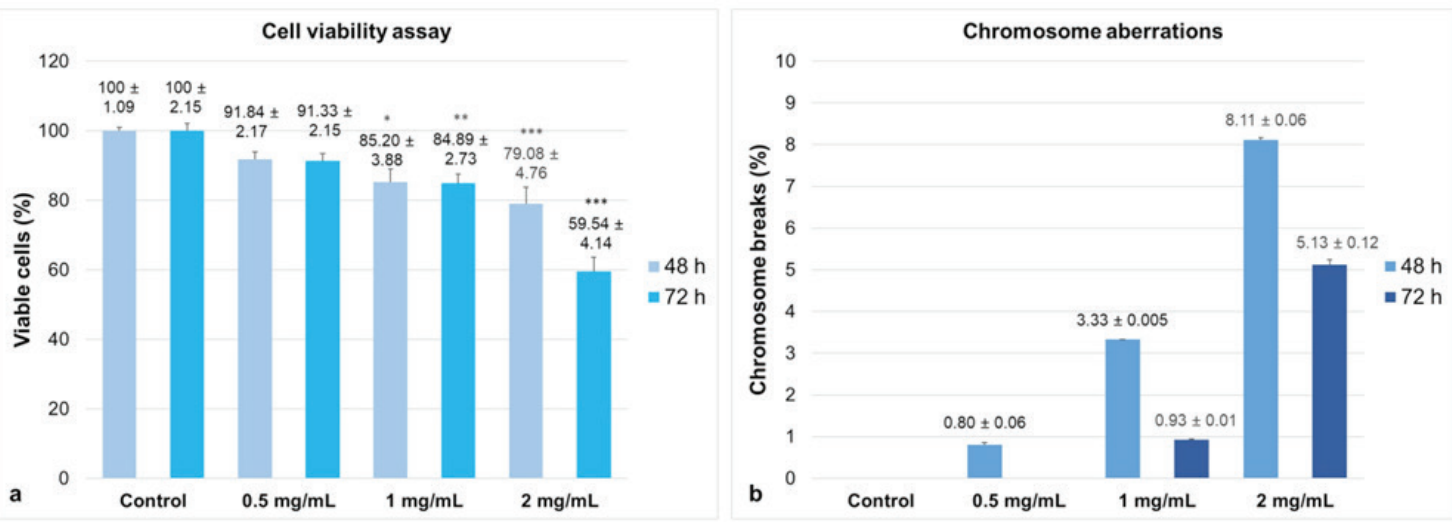

Figure 3 Cell viability expressed as percentage of control (a) and percentage of chromosome breaks (b) at different concentrations of yellow gentian root extract after 48 and $72 \mathrm{~h}$ treatment. ${ }^{*} \mathrm{p}<0.05,{ }^{* *} \mathrm{p}<0.01,{ }^{* * *} \mathrm{p}<0.001$

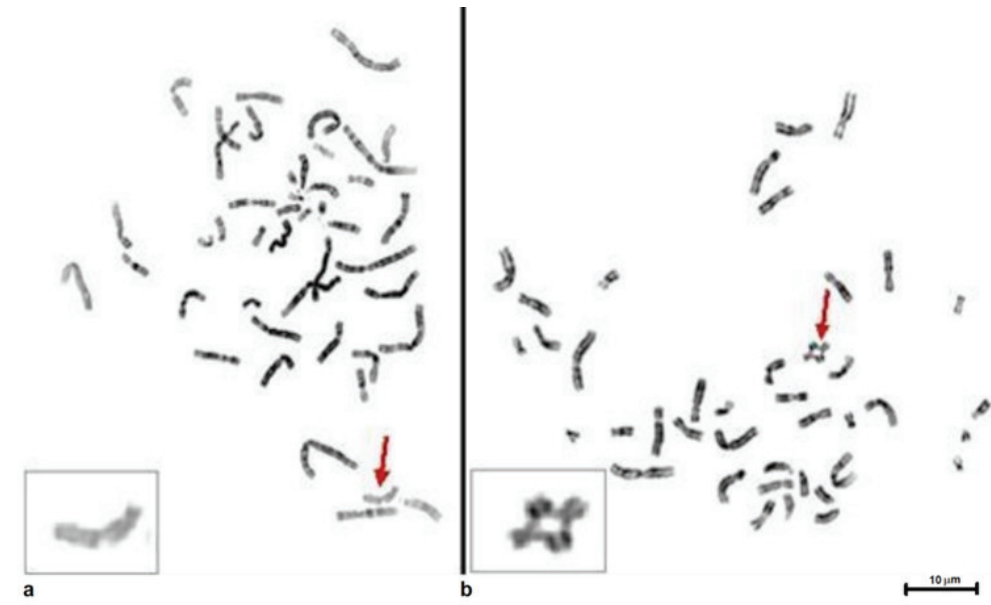

Figure 4 Photomicrograph of metaphase spreads after $72 \mathrm{~h}$ treatment with $2 \mathrm{mg} / \mathrm{mL}$ of yellow gentian root extract. Arrows mark chromatid break (a) and radial figure between two homologous chromosomes (17q) an indicator of homologous recombination - a mechanism of template-dependent DNA DSBs repair (b)

\section{Oxidative stress}

The levels of PAB and LPP were the highest $(67.9$ arbitrary $\mathrm{HK}$ units and $1.79 \mathrm{nmol} / \mathrm{mg}$ of proteins, respectively) and statistically significant for the lowest concentration of $0.5 \mathrm{mg} / \mathrm{mL}(\mathrm{p}<0.001)$, while they dropped toward control levels at higher concentrations (Figure 6). PAB and LPP positively correlated $(\mathrm{p}<0.01, \mathrm{r}=0.894)$.

\section{DISCUSSION}

Our results demonstrate concentration- and timedependent reduction in survival of PBMC after exposure to increasing concentrations of YGRE. Similar results were reported after treatment of human lymphocytes with extracts from other plants of the Gentianaceae family, which have similar constituents, such as Gentiana asclepiadea and Gentiana kurroo Royle $(25,26)$. Concentration-dependent cytotoxic effects of YGRE were, likewise, observed in cancer cell lines, such as cervical, breast, prostate and colon cancer $(14,15)$. However, cytotoxic outcomes in those studies were observed at lower concentrations, most likely due to differences in the metabolism of cancer cells and terminally differentiated peripheral blood T-lymphocytes. Different response to yellow gentian between malignant and healthy tissue was already observed in a study of its radioprotective effects (7).

In view of the contradictory literature data about the effects of yellow gentian, we wanted to see whether its cytotoxicity was associated with redox parameters and DNA damage, and found that only the lowest YGRE concentration increased redox parameters, which, however, led to only a minor DNA damage and mild cytotoxicity. Over the decades many studies focused on the relationship between oxidative stress and DNA damage, evidencing strong interplay between reactive oxygen species (ROS) production and DNA alterations that trigger genomic instability and cell death $(27,28)$. Our results indicate that pro-oxidant state and elevated lipid peroxidation products observed after treatment with the lowest YGRE concentration did not lead to significant DNA damage. In contrast, higher extract concentrations only slightly reduced PAB and LPP levels, but provoked significant DNA damage seen as an increased percentage of DNA in the comet tail and frequency of chromosomal aberrations. This may be due to the capacity 
of antioxidative defence, which is triggered only after a critical concentration of the tested compound is reached.

A comprehensive study by Kusar et al. (29) showed that YGRE displays strong antioxidative features by scavenging DPPH (2,2-diphenyl-1-picrylhydrazyl) and superoxide radical, but only at high concentrations of $19.0 \mathrm{mg} / \mathrm{mL}$ and $11.1 \mathrm{mg} / \mathrm{mL}$. Similar findings were reported by several studies, but all of them were obtained in ex vivo experiments $(4,14,30)$. The reported scavenging effect was probably due to the higher amount of constituents with antioxidant capacity, namely flavonoids, xanthones, and secoiridoids (31). Others $(32,33)$ demonstrated in vivo concentrationdependent antioxidative activity of $G$. cruciata and $G$. asclepiadea extracts rich in secoiridoids swertiamarin, sweroside, and gentiopicrin.

On the other hand, lower extract concentrations may favour pro-oxidant effects of other constituents, which leads to increased lipid peroxidation. The balance between extract constituents and their individual effects was well illustrated by Petrovic et al. (34), who found that a G. dinarica extract decreased lipid peroxidation products in peripheral blood lymphocytes, even though treatment with the same concentration of individual polyphenol compounds found in this plant generated opposite results. Isoorientin, isoorientin-4'-O-glycoside and norswertianin-1-Oprimveroside had antioxidative, while norswertianin-8-Oprimveroside and gentiacaulein displayed pro-oxidative effects. These results suggest that the cumulative outcome of plant extract mostly depends on the balance between its constituents and their individual pro-oxidative or antioxidative effects.

However, since higher extract concentrations induced significant DNA damage and reduced cellular survival, it is more likely that increasing YGRE concentrations provoke higher production of ROS, which consequently activate antioxidant enzymes such as SOD and catalase and endogenous antioxidant glutathione (GSH). Once activated, they could prevent oxidative damage within the cells to a certain extent, while a portion of cells is damaged beyond the repair capacity of terminally differentiated cells, as evidenced by diminished cell viability, and higher DNA damage. Treatment with $2 \mathrm{mg} / \mathrm{mL}$ of YGRE reduced cellular viability to $78.57 \%$, led to a significant increase of DNA \% in the comet tail (from 6.41 to $32.98 \%$ ) and produced $8.11 \%$ of chromosomal breaks after the 48 -hour treatment, whereas PAB and LPP levels dropped to nearly control values. With longer exposure $(72 \mathrm{~h}$ ) cytotoxicity was even more pronounced, as cell viability decreased to $59.54 \%$.

Other research groups also reported genotoxic and cytotoxic effects of different concentrations of Gentiana extracts. For instance, G. asclepiadea root extract increased comet tail length in rats treated with $400 \mathrm{mg} / \mathrm{kg}$ of body weight and dose-dependently increased comet tail intensity in human peripheral blood lymphocytes $(26,33)$. $G$.
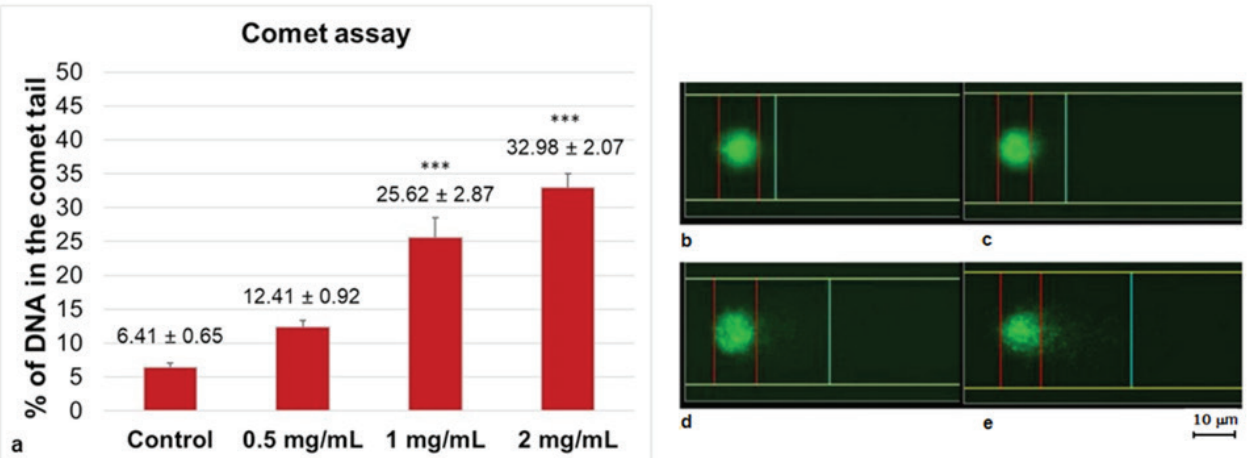

Figure 5 Graph (a) and photomicrograph (b-e) of YGRE-induced DNA damage established with the comet assay. b - control; c $0.5 \mathrm{mg} / \mathrm{mL} ; \mathrm{d}-1 \mathrm{mg} / \mathrm{mL} ; \mathrm{e}-2 \mathrm{mg} / \mathrm{mL}$; YGRE - yellow gentian root extract. Scale bar $-10 \mu \mathrm{m} .{ }^{* * *} \mathrm{p}<0.001$
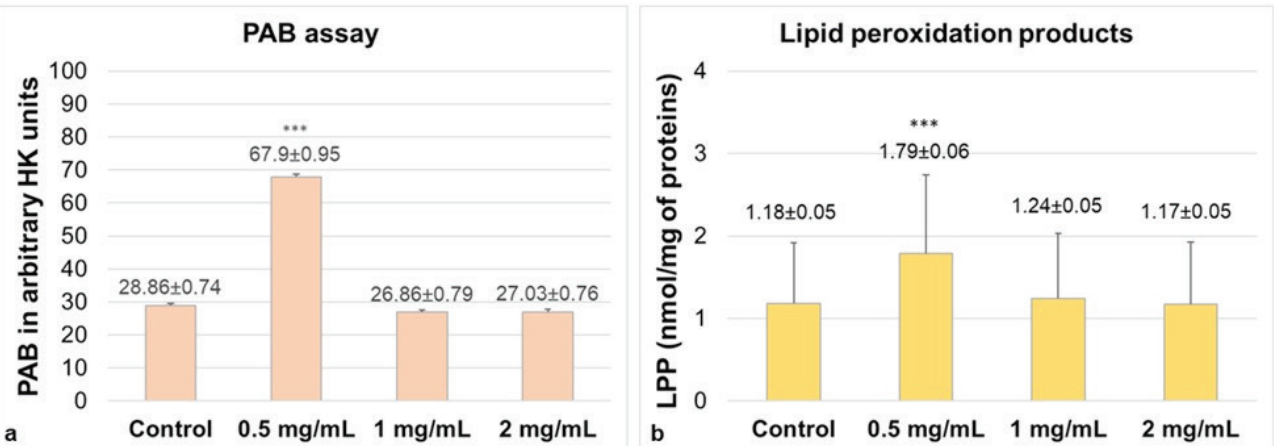

Figure 6 PAB levels presented as arbitrary HK units (a) and LPP levels expressed as nmol/mg of proteins (b) after treatment with increasing concentrations of yellow gentian root extract. $* * * p<0.001$ 
dinarica extract elevated the frequency of micronuclei and enhanced apoptosis in peripheral blood lymphocytes (34). Similar results were found for many plant extracts known for their antioxidant activity and rich in polyphenols, such as black and green tea extract, suggesting that higher polyphenol concentrations could lead to spontaneous $\mathrm{H}_{2} \mathrm{O}_{2}$ generation, DNA damage, and cell death $(35,36)$. In line with this argument, the concentration determines whether certain compound or extract acts as anti- or pro-oxidant.

Interestingly, in our study the frequency of chromosomal breaks was lower after $72 \mathrm{~h}$ of treatment for all tested concentrations. These and cell viability findings suggest that DNA repair mechanisms are activated in cells with aberrations that could be fixed, while the cells damaged beyond repair die. This is well illustrated by radial figures observed after $72 \mathrm{~h}$ of YGRE treatment, as they indicate homologous recombination, an important templatedependent DNA repair mechanism, specific for repair of double-strand breaks (DSBs). This is in accordance with the report by Patenković et al. (12), who demonstrated homologous mitotic recombination in Drosophila treated with YGRE (12). Even though homologous recombination could have negative effect due to loss of heterozygosity, activation of this repair mechanism is vital for the recovery from oxidative DNA damage $(12,37,38)$. Upon oxidative DNA damage, complex protein network activates, including ATM, ATR, RAD50 and MRE11A proteins, leading to upregulation of RAD50, RAD51, XRCC2 and XRCC3 gene and protein levels, which contribute to the survival of affected cells $(28,37,38)$.

\section{CONCLUSION}

The results of our study suggest that, although YGRE displayed concentration- and time-dependent cytotoxic and genotoxic effects, it activates repair mechanisms that counter oxidative and DNA lesions and induces cell death in cells damaged beyond repair. DNA fragmentation could serve to predict the cytotoxic effects of yellow gentian, as increased fragmentation was observed $24 \mathrm{~h}$ before significant increase in cell death. Considering these findings, it appears that the protective effects of yellow gentian result from the activation of cell defences and death of the cells beyond repair. However, since there is a clear correlation between concentration, treatment duration and toxic effects, and that these effects were observed at cell level, further studies are needed to get a better insight into the cyto/ genoprotective potential of YGRE, and this compound should be used with caution.

\section{Acknowledgement}

This work was financially supported by the Ministry of Education, Science and Technological Development of the Republic of Serbia.

\section{Conflict of interests}

None to declare.

\section{REFERENCES}

1. Pan Y, Zhao YL, Zhang J, Li WY, Wang YZ. Phytochemistry and pharmacological activities of the genus Gentiana (Gentianaceae). Chem Biodivers 2016;13:107-50. doi: 10.1002/cbdv.201500333

2. Mirzaee F, Hosseini A, Jouybari HB, Davoodi A, Azadbakht M. Medicinal, biological and phytochemical properties of Gentiana species. J Tradit Complement Med 2017;7:400-8. doi: 10.1016/j.jtcme.2016.12.013

3. Olennikov DN, Kashchenko NI, Chirikova NK, Tankhaeva LM. Iridoids and flavonoids of four Siberian gentians: chemical profile and gastric stimulatory effect. Molecules 2015;20(10):19172-88. doi: 10.3390/molecules201019172

4. Azman NAM, Segovia F, Martínez-Farré X, Gil E, Almajano MP. Screening of antioxidant activity of Gentian lutea root and its application in oil-in-water emulsions. Antioxidants (Basel) 2014;3:455-71. doi: 10.3390/antiox3020455

5. Savikin K, Menković N, Zdunić G, Stević T, Radanović D, Janković T. Antimicrobial activity of Gentiana lutea L. extracts. Z Naturforsch C J Biosci 2009;64:339-42. doi: 10.1515/znc-2009-5-606

6. Seiwerth J, Tasiopoulou G, Hoffmann J, Wölfle U, Schwabe K, Quirin KW, Schempp CM. Anti-inflammatory effect of a novel topical herbal composition (VEL-091604) consisting of gentian root, licorice root and willow bark extract. Planta Med 2019;85:608-14. doi: 10.1055/a-0835-6806

7. Menkovic N, Juranic Z, Stanojkovic T, Raonic-Stevanovic T, Savikin K, Zdunić G, Borojevic N. Radioprotective activity of Gentiana lutea extract and mangiferin. Phytother Res 2010;24:1693-6. doi: 10.1002/ptr.3225

8. Joksić G, Filipović Tričković J, Joksić I. Potential of Gentiana lutea for the treatment of obesity-associated diseases. Curr Pharm Des 2019;25:2071-6. doi: 10.2174/1381612825666 190708215743

9. Park E, Lee CG, Kim J, Yeo S, Kim JA, Choi CW, Jeong SY. Antiobesity effects of Gentiana lutea extract on 3T3-L1 preadipocytes and a high-fat diet- induced mouse model. Molecules 2020;25(10):2453. doi: 10.3390/ molecules 25102453

10. Kesavan R, Chandel S, Upadhyay S, Bendre R, Ganugula R, Potunuru UR, Giri h, Sahu G, Kumar PU, Reddy GB, Joksic G, Bera AK, Dixit M. Gentiana lutea exerts antiatherosclerotic effects by preventing endothelial inflammation and smooth muscle cell migration. Nutr Metab Cardiovasc Dis 2016;26:293-301. doi: 10.1016/j.numecd.2015.12.016

11. Kesavan R, Potunuru UR, Nastasijević B, Avaneesh T, Joksić G, Dixit M. Inhibition of vascular smooth muscle cell proliferation by Gentiana lutea root extracts. PLoS One 2013;8(4):e61393. doi: 10.1371/journal.pone.0061393

12. Patenković A, Stamenković-Radak M, Nikolić D, Marković T, Anđelković M. Synergistic effect of Gentiana lutea L. on methyl methanesulfonate genotoxicity in the Drosophila wing spot test. J Ethnopharmacol 2013;146:632-6. doi: 10.1016/j.jep.2013.01.027

13. Wani BA, Ramamoorthy D, Rather MA, Arumugam N, Qazi AK, Majeed R, Hamid A, Ganie SA, Ganai BA, Anand R, 
Gupta AP. Induction of apoptosis in human pancreatic MiaPaCa-2 cells through the loss of mitochondrial membrane potential $(\Delta \Psi \mathrm{m})$ by Gentiana kurroo root extract and LCESI-MS analysis of its principal constituents. Phytomedicine 2013;20:723-33. doi: 10.1016/j.phymed.2013.01.011

14. Balijagić J, Janković T, Zdunić G, Bosković J, Savikin K, Godevac D, Stanojković T, Jovancević M, Menković N. Chemical profile, radical scavenging and cytotoxic activity of yellow gentian leaves (Genitaneae luteaefolium) grown in northern regions of Montenegro. Nat Prod Commun 2012;7:1487-90. PMID: 23285813

15. Rodrigues C, Karmali A, Machado J. The extracts of Gentiana lutea with potential cytotoxic effects on human carcinoma cell lines: A preliminary study. Eur J Integr Med 2019;27:34-8. doi: 10.1016/j.eujim.2019.02.008

16. Ladeira C. Mycotoxins: genotoxicity studies and methodologies. In: Viegas C, Pinheiro AC, Sabino R, Viegas S, Brandão J, Veríssimo C, editors. Environmental mycology in public health. Amsterdam: Academic Press; 2016. p. 343-61. doi: 10.1016/B978-0-12-411471-5.00020-X

17. Strober W. Trypan blue exclusion test of cell viability. Curr Protoc Immunol 2015;111:A3.B.1-A3.B.3. doi: 10.1002/0471142735.ima03bs111

18. Organisation for Economic Cooperation and Development (OECD). Guidelines for the Testing of Chemicals No 473: In Vitro Mammalian Chromosomal Aberration Test. Paris:OECD; 2016. doi: 10.1787/9789264264649-en

19. Filipović J, Joksić G, Vujić D, Joksić I, Mrasek K, Weise A, Liehr, T. First molecular-cytogenetic characterization of Fanconi anemia fragile sites in primary lymphocytes of FAD2 patients in different stages of the disease. Mol Cytogenet 2016;9:70. doi: 10.1186/s13039-016-0280-6

20. Singh NP, McCoy MT, Tice RR, Schneider EL. A simple technique for quantitation of low levels of DNA damage in individual cells. Exp Cell Res 1988;175:184-91. doi: 10.1016/0014-4827(88)90265-0

21. Alamdari DH, Paletas K, Pegiou T, Sarigianni M, Befani C, Koliakos G. A novel assay for the evaluation of the prooxidant-antioxidant balance, before and after antioxidant vitamin administration in type II diabetes patients. Clin Biochem 2007;40:248-54. doi: $10.1016 / \mathrm{j}$. clinbiochem.2006.10.017

22. Esterbauer h, Schaur RJ, Zollner h. Chemistry and biochemistry of 4-hydroxynonenal, malonaldehyde and related aldehydes. Free Radic Biol Med 1991;11:81-128. doi: 10.1016/0891-5849(91)90192-6

23. Tsikas D. Assessment of lipid peroxidation by measuring malondialdehyde (MDA) and relatives in biological samples: Analytical and biological challenges. Anal Biochem 2017;524:13-30. doi: 10.1016/j.ab.2016.10.021

24. Valenta Sobot A, Savic J, Filipovic Trickovic J, Drakulic D, Joksic G. Toxicity assessment of Gentiana lutea L. root extract and its monoterpene compounds. Indian J Exp Biol 2020;58:609-16. URI: http://nopr.niscair.res.in/ handle/123456789/55047

25. Mubashir K, Ganai BA, Ghazanfar K, Akbar S, Rah B, Tantry M, Masood A. Anti-inflammatory and immuno-modulatory studies on LC-MS characterised methanol extract of Gentiana kurroo Royle. BMC Complement Altern Med 2017;17:78. doi: 10.1186/s12906-017-1593-7

26. Hudecová A, Hašplová K, Miadoková E, Magdolenová Z, Rinna A, Collins AR, Gálová E, Vaculčíková D, Gregán̆ F, Dušinská M. Gentiana asclepiadea protects human cells against oxidation DNA lesions. Cell Biochem Funct 2012;30:101-7. doi: 10.1002/cbf.1822

27. Alarifi S, Ali D, Alkahtani S, Verma A, Ahamed M, Ahmed M, Alhadlaq HA. Induction of oxidative stress, DNA damage, and apoptosis in a malignant human skin melanoma cell line after exposure to zinc oxide nanoparticles. Int J Nanomedicine 2013;8:983-93. doi: 10.2147/IJN.S42028

28. Van Houten B, Santa-Gonzalez GA, Camargo M. DNA repair after oxidative stress: Current challenges. Curr Opin Toxicol 2018;7:9-16. doi: 10.1016/j.cotox.2017.10.009

29. Kusar A, Zupancic A, Sentjurc M, Baricevic D. Free radical scavenging activities of yellow gentian (Gentiana lutea L.) measured by electron spin resonance. Hum Exp Toxicol 2006;25:599-604. doi: 10.1177/096032706072467

30. Nastasijević B, Lazarević-Pašti T, Dimitrijević-Branković S, Pašti I, Vujačić A, Joksić G, Vasić V. Inhibition of myeloperoxidase and antioxidative activity of Gentiana lutea extracts. J Pharm Biomed Anal 2012;66:191-6. doi: 10.1016/j.jpba.2012.03.052

31. Halliwell B, Aeschbach R, Löliger J, Aruoma OI. The characterization of antioxidants. Food Chem Toxicol 1995;33:601-17. doi: 10.1016/0278-6915(95)00024-v

32. Mihailović V, Katanić J, Mišić D, Stanković V, Mihailović M, Uskoković A, Arambašić J, Solujić S, Mladenović M, Stanković N. Hepatoprotective effects of secoiridoid-rich extracts from Gentiana cruciata L. against carbon tetrachloride induced liver damage in rats. Food Funct 2014;5:1795-803. doi: 10.1039/c4fo00088a

33. Mihailović V, Mihailović M, Uskoković A, Arambašić J, Mišić D, Stanković V, Katanić J, Mladenović M, Solujić S, Matić S. Hepatoprotective effects of Gentiana asclepiadea L. extracts against carbon tetrachloride induced liver injury in rats. Food Chem Toxicol 2013;52:83-90. doi: 10.1016/j. fct.2012.10.034

34. Petrovic S, Leskovac A, Joksic G. Radioprotective properties of Gentiana dinarica polyphenols on human lymphocytes in vitro. Curr Sci (Bangalore) 2008;95:1035-41.

35. Ježovičová M, Koňariková K, Duračková Z, Keresteš J, Králik G, Žitňanová I. Protective effects of black tea extract against oxidative DNA damage in human lymphocytes. Mol Med Rep 2016;13:1839-44. doi: 10.3892/mmr.2015.4747

36. Elbling L, Weiss R-M, Teufelhofer O, Uhl M, Knasmueller S, Schulte-Hermann R, Berger W, Micksche M. Green tea extract and (-)-epigallocatechin-3-gallate, the major tea catechin, exert oxidant but lack antioxidant activities. FASEB J 2005;19:807-9. doi: 10.1096/fj.04-2915fje

37. Hayashi M, Umezu K. Homologous recombination is required for recovery from oxidative DNA damage. Genes Genet Syst 2017;92:73-80. doi: 10.1266/ggs.16-00066

38. Wang C, Yang J, Lu D, Fan Y, Zhao M, Li Z. Oxidative stress-related DNA damage and homologous recombination repairing induced by $N, N$-dimethylformamide. J Appl Toxicol 2016;36:936-45. doi: 10.1002/jat.3226 


\section{Učinak ekstrakta korijena žute lincure na mononuklearne stanice periferne krvi ovisi o njegovoj koncentraciji i vremenu izlaganja}

Žuta lincura (Gentiana lutea L.), ljekovita biljka koja se često koristi u tradicionalnoj medicini, pokazuje višestruke biološke učinke, od korisnih do toksičnih. Budući da je do sada zabilježeno mnogo mogućih primjena, cilj nam je bio procijeniti potencijalne citotoksične i genotoksične učinke ekstrakta korijena te biljke, koji ovise o njegovoj koncentraciji i vremenu izlaganja in vitro. Mononuklearne stanice ljudske periferne krvi izložili smo ekstraktu korijena žute lincure (YGRE), koncentracije $0,5 \mathrm{mg} / \mathrm{mL}, 1 \mathrm{mg} / \mathrm{mL}$ i $2 \mathrm{mg} / \mathrm{mL}$, da bismo utvrdili njegove učinke na parametre oksidacijskoga stresa [pro/antioksidacijski balans (PAB) i peroksidacija lipida], oštećenja DNA (alkalni komet test i kromosomske aberacije) i preživljavanje stanica (tripan plavo bojenje). Preživljavanje stanica smanjivalo se s povećanjem koncentracije i trajanja izlaganja. Samo najniža koncentracija YGRE-a $(0,5 \mathrm{mg} / \mathrm{mL})$ dovela je do povećanja oksidacijskoga stresa, ali je proizvela manja oštećenja DNA i citotoksičnost. Pri višim koncentracijama, redoks parametri vratili su se blizu razine kontrolnih vrijednosti. Postotak kromosomskih aberacija i postotak DNA u repu kometa povećavao se s povećanom koncentracijom YGRE-a nakon 48 sati i smanjivao nakon 72 sata tretmana. To upućuje na aktiviranje mehanizma popravka DNA (homologna rekombinacija), što dokazuje prisutnost kromosomskih radijalnih struktura nakon 72 sata tretmana najvišom koncentracijom YGRE-a od $2 \mathrm{mg} / \mathrm{mL}$. Naši rezultati pokazuju da YGRE, unatoč induciranju citotoksičnih i genotoksičnih učinaka, aktivira mehanizme popravka stanica koji suzbijaju oksidacijske i DNA lezije i induciraju smrt visoko oštećenih stanica. Zaključak je da uočeni zaštitni učinci dužeg izlaganja ekstraktu korijena žute lincure mogu biti rezultat aktivnoga popravka i uklanjanja stanica s nepopravljivim oštećenjima.

KLJUČNE RIJEČI: citotoksičnost; genotoksičnost; Gentiana lutea L.; homologna rekombinacija; redoks parametri 